\title{
Effect of size and sex ratio of litter on the sexual maturation of female mice
}

\author{
L. C. Drickamer \\ Biology Department, Williams College, Williamstown, Massachusetts 01267, U.S.A.
}

\begin{abstract}
Summary. The relationships between the size and sex composition of the litter and puberty in female mice were investigated. Both factors significantly affected the age of first vaginal oestrus; litter size accounted for $22 \%$ of the total variation in age at puberty, and litter sex composition for $8 \%$. When no males or only one male was present in litters of 10 young the females matured significantly earlier than when two or more males were present.
\end{abstract}

\section{Introduction}

Reports of some investigations of factors affecting sexual development in female mice (Montiero \& Falconer, 1966; Castro, 1967; Vandenbergh, 1967, 1969; Vandenbergh, Drickamer \& Colby, 1972; Cowley \& Wise, 1972) have not specified the sizes or sex compositions of the litters used. Kennedy \& Brown (1970) used litters of 4 female young and Fullerton \& Cowley (1971) studied litters which varied from 3 to 8 females. Standard litter sizes of 8-10 young that included at least one male were used by Colby \& Vandenbergh (1974) and Drickamer (1974a, b, 1975a, b).

Litter size and sex composition could affect the timing of sexual development in the mouse, either directly by some pheromonal type of mechanism or indirectly by affecting body growth. In the present experiments the separate effect of each factor on sexual maturation in female mice was examined.

\section{Materials and Methods}

The ICR/ALB mice were from a randomly bred closed colony. All colony and test mice were housed in shoe-box cages of polypropylene measuring $15 \times 28 \times 15 \mathrm{~cm}$ with opaque sides and fitted wire lids. Colony and experimental rooms were maintained at $21-25^{\circ} \mathrm{C}$ and $30-60 \%$ relative humidity on a 12-hr light:12-hr dark lighting regimen. Bedding of ground wood shavings was changed once per week. Wayne Lab-blox and water were freely supplied.

Pregnant female mice were placed in individual cages 1 week before parturition. All cages were then checked daily and births were recorded. On the day after birth the young in each litter were counted and sexed, and the litter manipulated by culling and/or cross-fostering to provide the litter size and sex composition desired.

At weaning, at 21 days of age, each test mouse was caged singly and was examined daily until the occurrence of vaginal perforation. Starting on the day of vaginal perforation, a vaginal lavage was performed each day until the occurrence of first vaginal oestrus, as determined by the criteria of Vandenbergh (1969) and Vandenbergh et al. (1972). Each mouse was weighed to the nearest $0.1 \mathrm{~g}$ on the days of vaginal perforation and first oestrus, and on Days $21,28,35$, and 42 of age.

\section{Experiment I}

The effect of different numbers of males and a constant litter size was investigated.

On the day after birth each of 200 litters was reduced to 10 young and litters were manipulated to contain $1,2,3,4,5,6,7,8,9$, or 10 females (20 litters of each composition). Each reconstituted 
litter contained as many of the original young as possible. At weaning 1 female was selected at random from each litter, providing a sample size of $20 /$ treatment, and checked daily until first vaginal oestrus occurred.

\section{Experiment II}

The combined effects of the size and sex composition of the litter were tested.

On the day after birth 256 litters were manipulated to provide 64 litters with 4, 8, 12 or 16 young. For each litter size the number of females was arranged to be $25 \%, 50 \%, 75 \%$, or $100 \%$ of the litter (see Table 2), thus providing 16 litters for each of 16 cells in this cross-classified design. At weaning 1 female was selected at random from each litter to give a sample size of 16 mice/treatment combination and checked as described above until first vaginal oestrus.

\section{Experiment III}

The combined effects of litter size and sex composition was determined for litters as they were born, i.e. with no manipulations.

On the day after birth the young in each of the litters of 66 females were counted and sexed. At weaning 1 female was randomly selected from each litter to give a sample size of 66 females which were checked daily until first vaginal oestrus. The results were analysed with a two-factor multiple regression (Snedecor \& Cochran, 1967).

\section{Results}

\section{Experiment $I$}

Analysis-of-variance and Duncan's New Multiple Range Test showed that mice reared in litters containing no males or only 1 male reached first oestrus at significantly earlier mean ages $(F=3 \cdot 04$; d.f. $=9,190 ; P<0.01)$ than mice from litters containing two or more males (Table 1). There was also significant variation in the ages at vaginal perforation $(\mathrm{F}=1.94$; d.f. $=9,190 ; P<0.05)$ and mean body weights of females at first oestrus $(\mathrm{F}=3.65$; d.f. $=9,190 ; P<0.01)$, but the distinctions for the sex ratios were not clear-cut (Table 1). There were no significant differences for mean body weights at $21,28,35$, or 42 days of age, or at the age of vaginal perforation.

\section{Experiment II}

Analysis-of-variance and Duncan's New Multiple Range Test revealed that mice reared in litters of 4 attained puberty significantly earlier $(\mathrm{F}=27.49 ;$ d.f. $=3,240 ; P<0.01)$ than mice in litters of 8 or 12, and mice from litters of 16 matured still later (Table 2). Mice from $100 \%$ female litters matured significantly earlier $(\mathrm{f}=5 \cdot 14$; d.f. $=3,240 ; P<0.01)$ than mice from litters containing $25-75 \%$ females. There was no significant interaction between the size and sex composition variables. The analysis also revealed that $22 \%$ of the variation in age at first oestrus was accounted for by the treatment variation in litter size, while $8 \%$ of the variation was attributable to the differences in litter sex composition. Analysis of data for age at vaginal perforation showed similar patterns of significant differences with respect to the litter size treatment factor, but not for litters of different sex composition.

Whatever the size of the litter mice exhibited vaginal perforation and attained first oestrus at the same mean body weight. Mice from litters with different sex compositions also exhibited vaginal perforation at the same mean body weights, but attained first oestrus at significantly different body weights ( $\mathrm{F}=3.68$; d.f. $=3,240 ; P<0.01)$; all-female litters, $21.8 \mathrm{~g}, 25 \%$ females, $23.4 \mathrm{~g}, 50 \%$ females, $23.0 \mathrm{~g}$, and $75 \%$ females, $23.6 \mathrm{~g}$. There were no significant interactions between the litter size and sex composition treatment factors for analyses of body weights at vaginal perforation or first oestrus. 


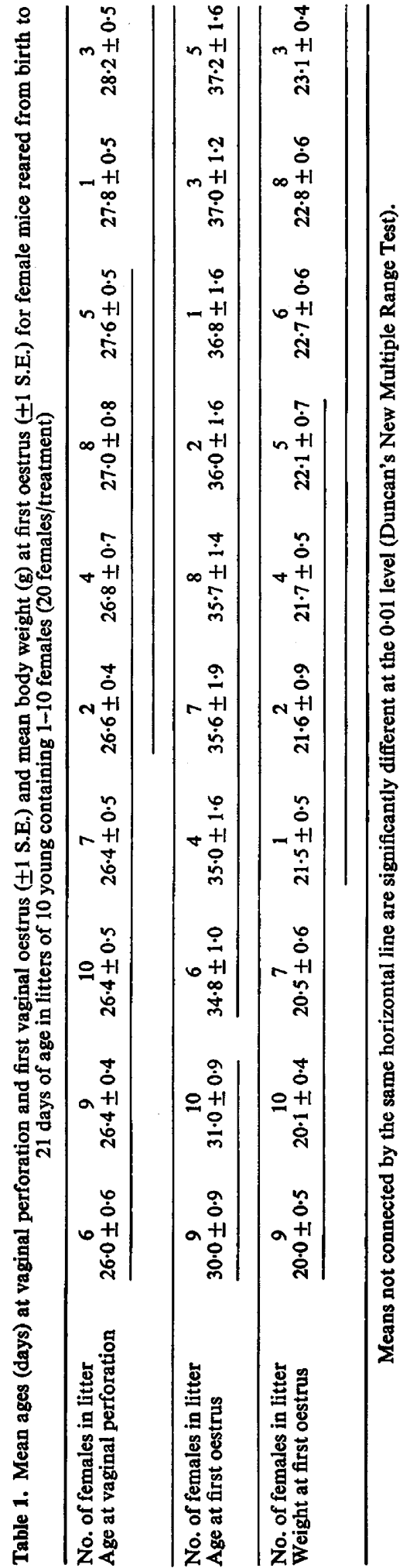


Table 2. Mean ( \pm 1 S.E.) age, in days, for first vaginal oestrus in female mice reared in litters of four different sizes with four different female:male ratios $(\mathrm{N}=16 /$ treatment combination)

\begin{tabular}{|c|c|c|c|c|c|}
\hline \multirow{2}{*}{$\begin{array}{l}\text { Litter } \\
\text { size }\end{array}$} & \multicolumn{4}{|c|}{ Female composition $(\%)$} & \multirow[b]{2}{*}{ Mean } \\
\hline & 25 & 50 & 75 & 100 & \\
\hline 4 & $31 \cdot 1 \pm 1 \cdot 2$ & $31 \cdot 4 \pm 1 \cdot 0$ & $31 \cdot 1 \pm 0.9$ & $28 \cdot 1 \pm 0.7$ & $\mid 30 \cdot 4$ \\
\hline $\begin{array}{r}8 \\
12\end{array}$ & $\begin{array}{l}35.2 \pm 1.6 \\
35.4 \pm 1.3\end{array}$ & $\begin{array}{l}33 \cdot 2 \pm 1 \cdot 2 \\
36 \cdot 5 \pm 1 \cdot 6\end{array}$ & $\begin{array}{l}33 \cdot 2 \pm 1 \cdot 1 \\
35 \cdot 9 \pm 2 \cdot 0\end{array}$ & $\begin{array}{l}32 \cdot 1 \pm 0 \cdot 8 \\
33 \cdot 1 \pm 1 \cdot 0\end{array}$ & $\begin{array}{l}33 \cdot 4 \\
35 \cdot 2\end{array}$ \\
\hline 16 & $38.1 \pm 1.0$ & $38.2 \pm 1.0$ & $37.4 \pm 0.9$ & $35.6 \pm 0.9$ & $37 \cdot 4$ \\
\hline Mean & $35 \cdot 0$ & $34 \cdot 8$ & $34 \cdot 4$ & $32 \cdot 2$ & \\
\hline
\end{tabular}

Means not connected by the same vertical or horizontal line are significantly different at the 0.01 level (Duncan's New Multiple Range Test).

Mean weekly body weights did not differ for females from litters of different sex composition, but were significantly different for mice from litters of different sizes $(F=153.64 ; d . f=3,240 ; P<0.01)$. In general, females from larger litters weighed significantly less at weaning, but grew more rapidly in the first 2 weeks after weaning (Table 3).

Table 3. Mean ( \pm 1 S.E.) body weight, in $g$, at four weekly age intervals for mice reared in litters of four different sizes ( $N=64 /$ treatment)

\begin{tabular}{|c|c|c|c|c|}
\hline \multirow{2}{*}{$\begin{array}{c}\text { Litter } \\
\text { size }\end{array}$} & \multicolumn{4}{|c|}{ Age (days) } \\
\hline & 21 & 28 & 35 & 42 \\
\hline 4 & $\mid 15.8 \pm 0.3$ & $21.9 \pm 0.3$ & $24.8 \pm 0.2$ & $26.2 \pm 0.6$ \\
\hline 8 & $13.3 \pm 0.4$ & $20.7 \pm 0.2$ & $24.2 \pm 0.4$ & $24.7 \pm 0.6$ \\
\hline 12 & $10.5 \pm 0.2$ & $18.5 \pm 0.2$ & $22.6 \pm 0.4$ & $24.3 \pm 0.3$ \\
\hline 16 & $8.8 \pm 0.4$ & $16 \cdot 1 \pm 0.4$ & $21.4 \pm 0.4$ & $23.2 \pm 0.5$ \\
\hline
\end{tabular}

Means not connected by the same vertical line are significantly different at the 0.01 level (Duncan's New Multiple Range Test).

\section{Experiment III}

Litter sizes ranged from 3 to 18 young and the litter sex composition varied from $15 \%$ to $100 \%$ female. Regression analysis showed that litter size and sex composition were related to the age at maturation by the equation: $Y=20 \cdot 59+0 \cdot 764 X_{1}-0.080 X_{2}$, where $Y$ is age at first oestrus, $X_{1}$ is litter size and $\mathrm{X}_{2}$ is litter sex composition expressed as the percentage of females in the litter. Testing each factor after removing the effect of the other revealed that both were significant factors affecting the timing of puberty, but that only litter size was a significant source of variation alone in the total regression (Table 4).

\section{Discussion}

The size and sex composition of the litter have been shown to influence puberty in young female mice. For the sex composition factor there is no consistent overall trend or pattern in the timing of puberty and the effect appears to be 'all or none'. The mechanism to account for the earlier maturation in some litters may involve various factor(s) which change when the sex composition of a litter exceeds one male. Conversely, the change may relate to factor(s) which are activated when the young in a litter are entirely or almost entirely female.

Male offspring may compete more successfully for the dam's milk, or be preferentially provided with it by selective behaviour of the mother, and thus retard the growth of their sibling females, affecting puberty via a body-weight mechanism (Montiero \& Falconer, 1966). However, the results 
Table 4. Multiple regression analyses of iitter size $\left(\mathrm{X}_{1}\right)$, litter sex composition $\left(\mathrm{X}_{2}\right)$ and the age of first vaginal oestrus

\begin{tabular}{lrccc}
\hline a) Source of variation & \multicolumn{1}{c}{ d.f. } & Mean sum of squares & $F$ & $P$ \\
\hline Regression $\left(\mathrm{X}_{1} \times \mathrm{X}_{2}\right)$ & 2 & 158.30 & 10.58 & $<0.01$ \\
Deviations & 64 & 14.96 & & \\
Total & 66 & $\left(\mathrm{SS}_{\mathrm{T}}=1274.00\right)$ & & \\
$\mathrm{X}_{1}$ alone & 1 & 242.95 & 16.24 & $<0.01$ \\
$\mathrm{X}_{2}$ after $\mathrm{X}_{1}$ & 1 & 73.65 & 4.92 & $<0.05$ \\
$\mathrm{X}_{2}$ alone & 1 & 31.57 & 2.11 & $\mathrm{~N} . \mathrm{S}$. \\
$\mathrm{X}_{1}$ after $\mathrm{X}_{2}$ & 1 & 285.03 & 19.06 & $<0.01$ \\
\multicolumn{1}{c}{ Multiple $\mathrm{R}^{2}=0.249 ; \mathrm{F}=10.44 ;$ d.f. $=2,63 ; P<0.01$} & \\
\hline b) Two variable correlation coefficients & & $r$ & $P$ \\
\hline Litter size $\times$ age at maturation & & 0.437 & $<0.01$ \\
Litter sex composition $\times$ age at maturation & -0.157 & N.S. \\
Litter size $\times$ litter sex composition & 0.170 & N.S. \\
\hline
\end{tabular}

c) Regression coefficients

$b_{1}$ (litter size $\times$ age at maturation) $=0.764 \pm 0.173$

$b_{2}$ (litter sex composition $\times$ age at maturation) $=-0.080 \pm 0.035$

of Exp. I showed that mean body weight for females from all 10 sex composition treatments did not differ significantly at 21 days of age.

There are at least two ways in which males in a litter could affect puberty via mechanisms involving social behaviour. If male young excrete a pheromone, or affect females in some other manner by their presence, then the cumulative effect of two or more males might alter the timing of puberty. If this were true a progressive effect could be expected as the number of males in the litter increased, but data from Experiment I contradict this notion: any pheromone produced by the males appears to have a delaying effect on sexual development. Vandenbergh (1967) and Colby \& Vandenbergh (1974) have already shown that adult males excrete a urinary pheromone which accelerates sexual maturation of female mice. The present hypothesis would necessitate either a change in the nature of male pheromone(s) as the male mice mature, or a change in the response of female mice to male pheromone(s). Alternatively, two or more male offspring may affect each other to cause behavioural or chemical changes among the young which in turn influence sexual maturation of litter-mate females.

The developmental stage when the effect of litter sex composition takes place cannot be determined directly from the results of the present three experiments. Clemens (1974) has reported that position in utero can affect the degree of masculine behaviour exhibited by female mice; females between two males show more male-like behaviour as adults than females next to only one male or none. In an analogous manner the uterine position of a female embryo could influence the time of puberty. The results from Exps I and II, in which there was some litter manipulation, particularly in reconstituting litters with few or no males, could be taken to support an hypothesis that the effect of litter sex composition on maturation occurs during the 21 days between birth and weaning.

Mice from litters of different sizes all attained first oestrus at similar mean body weights, yet there were significant differences in average weights at all four weekly weighing intervals for females from the different litter size treatments. These data suggest that variations in the age of first oestrus for mice from litters of different sizes may be a function of a mechanism involving body weight. Previous investigations (Kennedy \& Mitra, 1963; Montiero \& Falconer, 1966) have demonstrated that, under some conditions, sexual maturation in rats and mice is closely related to morphological development and that animals attain puberty only after reaching a particular body weight. In Exp. II mice from smaller litters were heavier at weaning and thus needed to gain less weight to reach the 'critical' weight triggering puberty than mice from larger litters that weighed less at weaning. A similar critical body weight hypothesis has been proposed for the mechanism controlling the onset 
of puberty in man (Frisch \& Revelle, 1969, 1970). Other studies on mice have demonstrated that, under some conditions, the programmes for sexual and morphological development may act independently (Vandenbergh, 1969; Vandenbergh et al., 1972; Drickamer, 1974a).

Whatever the mechanism of action, the present studies have shown that litter sizes within and between studies should be held constant. Litters of different sex composition can be used, but the female:male ratio should be specified, and litters should be $100 \%$ female, or every litter should contain two or more males. Since there are strain differences in the timing of sexual maturation, however, there may also be variations between mouse strains for the effects of litter size and sex composition.

This work was supported in part by United States Public Health Service Grants MH-24483 and HD-08585 and Sloan Foundation Discretionary Funds at Williams College. I thank Dr John Vandenbergh, Dr John A. King, Dr E. J. Eisen and Dr T. E. McGill for reading the manuscript.

\section{References}

Castro, B.M. (1967) Age of puberty in female mice: relationship to population density and the presence of adult males. Anais Acad. bras. Cienc. 39, 289-292.

Clemens, L.C. (1974) Neurohormonal control of male sexual behavior. In Reproductive Behavior, pp. 264 288. Eds W. Montagna \& W. A. Sadler. Plenum Press, New York.

Colby, D.R. \& VANDENBerGH, J.G. (1974) Regulatory effects of urinary pheromones on puberty in the mouse. Biol. Reprod. 11, 268-279.

CowLEY, J.J. \& WISE, D.R. (1972) Some effects of mouse urine on neonatal growth and reproduction. Anim. Behav. 20, 499-506.

Drickamer, L.C. (1974a) Sexual maturation of female mice: social inhibition. Devl Psychobiol. 7, 257-265.

DriCKamer, L.C. (1974b) Contact stimulation, androgenized females and accelerated sexual development in female mice. Behav. Biol. 12, 101-110.

Drickamer, L.C. (1975a) Daylength and sexual maturation of female house mice. Devl Psychobiol. (in press).

Drickamer, L.C. (1975b) Female mouse maturation: interactions of social factors and daylength. $J$. Reprod. Fert. 44, 147-150.

Frisch, R.E. \& ReVelle, R. (1969) The height and weight of adolescent boys and girls at the time of peak velocity of growth in height and weight: longitudinal data. Hum. Biol. 41, 185-192.

Frisch, R.E. \& RBVELLE, R. (1970) Height and weight at menarche and a hypothesis of critical body weights and adolescent events. Science, N.Y. 169, 397-399.

Fullerton, C. \& Cowley, J.J. (1971) The differential effect of the presence of adult male and female mice on the growth and development of the young. $J$. Genet. Psychol. 119, 89-98.

KenNedy, G.C. \& Brown, K. (1970) Effects of male odor during infancy on the maturation, behavior and reproduction of female mice. Devl Psychobiol. 3, 179-189.

Kennedy, G.C. \& MitrA, J. (1963) Body-weight and food intake as initiating factors for puberty in the rat. J. Physiol., Lond. 166, 408-419.

Montiero, L.S. \& Falconer, D.S. (1966) Compensatory growth and sexual maturity in mice. Anim. Prod. 8, 179-192.

Snedecor, G.W. \& Cochran, W.G. (1967) Statistical Methods, 6th edn. Iowa State University Press, Ames, Iowa.

VANDENBERGH, J.G. (1967) Effect of the presence of a male on the sexual maturation of female mice. Endocrinology 81, 345-349.

VANDENBERGH, J.G. (1969) Male odor accelerates female sexual maturation in mice. Endocrinology 84, 658660.

VAndenbergh, J.G., Drickamer, L.C. \& Colby, D.R. (1972) Social and dietary factors in the sexual maturation of female mice. J. Reprod. Fert. 28, $397-405$.

Received 15 July 1975 